\title{
Variaciones en el metabolismo energético de la alpaca (Vicugna pacos). Una evaluación por efecto del ayuno prolongado
}

Variations in the energy metabolism of the alpaca (Vicugna pacos). An evaluation by effect of pro-

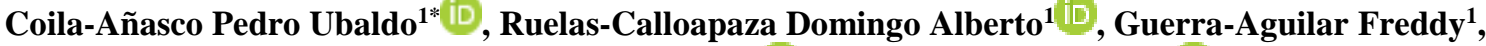 \\ Olaguivel Flores César Augusto ${ }^{2}$, Oha-Humpiri Filiberto ${ }^{3}[$
}

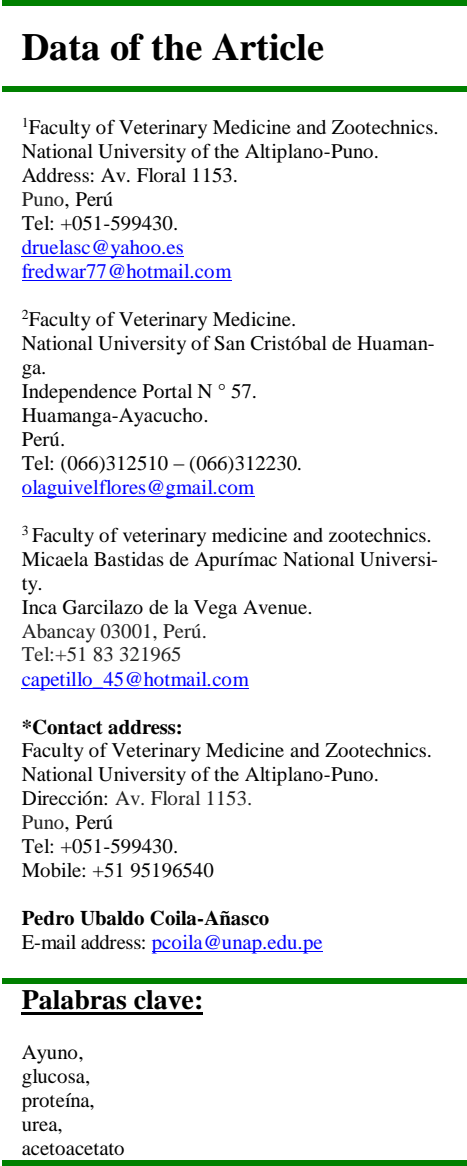

J. Selva Andina Anim. Sci. 2020; 7(2):63-71. ID of article: 079/JSAAS/2020

\section{Record from the article.}

Received July 2020.

Returned August 2020

Accepted September 2020

Available online October 2020.

Editado por:

Selva Andina

Research Society longed fasting

\section{Resumen}

El estudio tuvo como objetivo de evaluar el efecto de un ayuno prolongado ( 5 días) sobre algunos componentes bioquímicos sanguíneos involucrados en el metabolismo energético. Se utilizaron 20 alpacas macho de dos años de edad en dos tratamientos (experimental y control). Se tomaron muestras de sangre en horas de la mañana por cinco días para cuantificar los niveles séricos de glucosa, proteínas y urea por espectrofotometría y cuerpos cetónicos mediante tiras reactivas en forma semicuantitativa. Los resultados muestran que el promedio de glucosa, proteínas y urea de las alpacas sometidas a ayuno son diferentes al grupo control ( $\mathrm{P} \leq 0.05)$. Los niveles de glucosa disminuyen mientras que los niveles de proteínas y urea aumentan con el paso del tiempo. La presencia de acetoacetato no fue detectada durante los cinco días de ayuno. Se concluye que el ayuno prolongado en alpacas altera el proceso metabólico del animal, tanto cuantitativa como cualitativamente, modificándose los sustratos y productos implicados en la producción de energía.

2020. Journal of the Selva Andina Animal Science ${ }^{\circledR}$. Bolivia. Todos los derechos reservados.

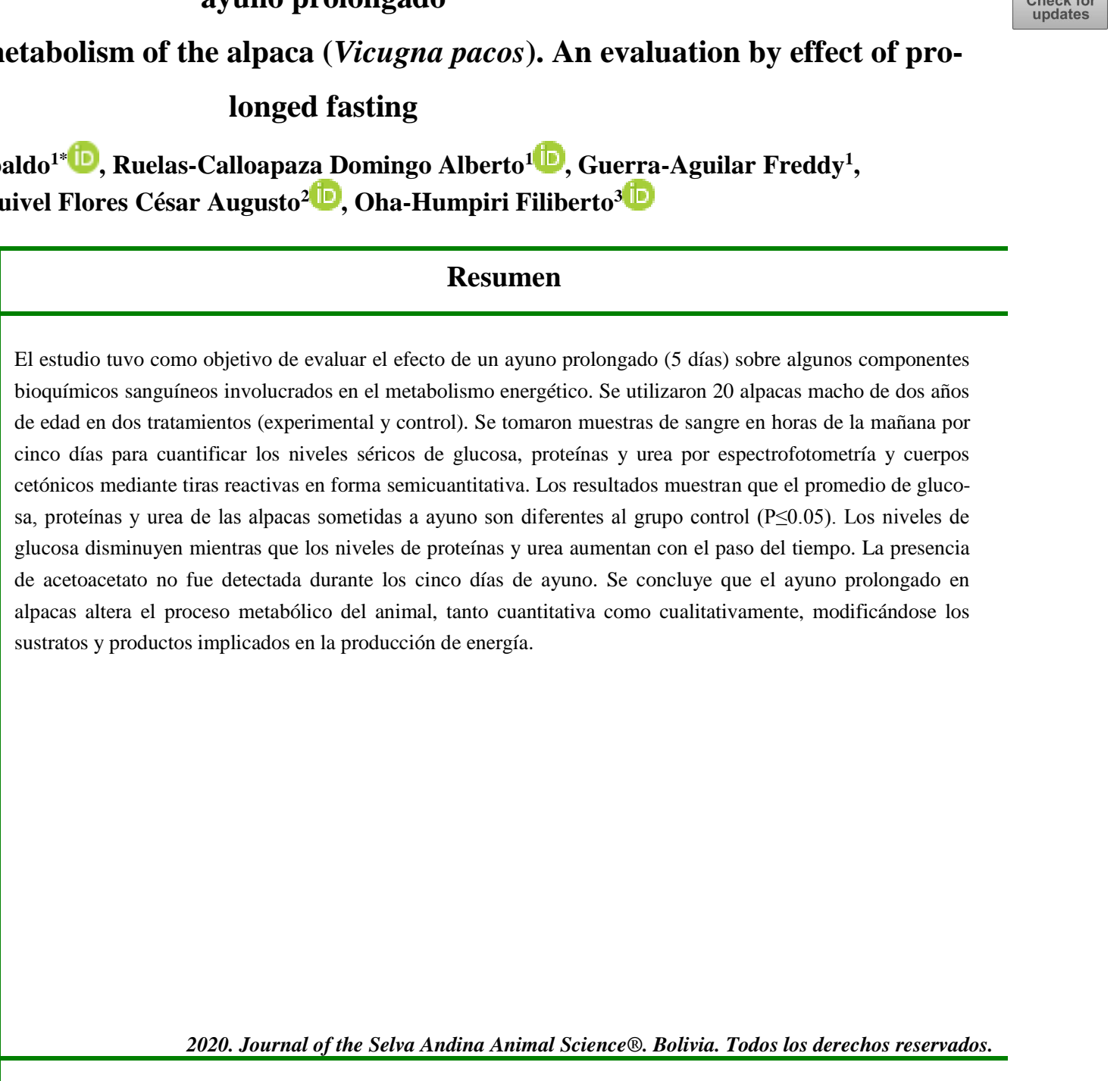

Abstract

The study aimed to evaluate the effect of a prolonged fast (5 days) on some blood biochemical components involved in energy metabolism. Twenty male alpacas of two-year-old were used in two treatments (experimental and control). Blood samples were taken in the morning for five days to quantify serum glucose, protein, and urea levels by spectrophotometry and ketone bodies using semi quantitative test strips. The results show that the average glucose, protein, and urea of the alpacas subjected to fasting are different from the control group $(\mathrm{P} \leq 0.05)$. Glucose levels decrease while protein, and urea levels increase over time. The presence of acetoacetate was not detected during the five days of fasting. It is concluded that prolonged fasting in alpacas alters the animal's metabolic process, both quantitatively and qualitatively, modifying the substrates and products involved in energy production. 


\section{Keywords:}

\section{Introduction}

For years it has been recognized that South American Camelids (CSAs) tend to have higher blood glucose concentrations than domestic ruminants, which is puzzling because CSAs, like other ruminants, are also fermenters; It is not possible to think that the carbohydrates in the diet escape from gastric microbial fermentation, so these species depend on gluconeogenesis to supply the necessary substrate to glucose-dependent tissues. Furthermore, in recent years, diseases have been identified in alpacas and llamas, which appear to be the result of abnormal carbohydrate metabolism. Some of these alterations resemble those of other animals, but others do not; these differences support the conclusion that CSAs process carbohydrates differently from other animals ${ }^{1}$.

Faced with a decrease in food consumption, the animal organism activates mechanisms that lead to the production of substrates that ensure the supply of energy to the vital organs, in order to ensure the survival of the animal, and, if the fast continues, the metabolism is changing both qualitatively and quantitatively $^{2}$. During fasting, initially, the energy substrates derive from protein and fat degradation, but in the following phases, protein degradation slows down, maximizing lipolysis ${ }^{3}$. Gluconeogenesis is a metabolic pathway that is permanently active in ruminants, with propionic acid being the main precursor of glucose synthesis ${ }^{4}$. Likewise, it seems that alpacas depend on their digestive and metabolic adaptations to obtain, efficiently conserve energy to survive in environments where the available food varies in nutritional quality ${ }^{5}$.

Another important source of energy is amino acids, which are mobilized after blood hypoglycemia in order to support hepatic gluconeogenesis and, therefore, energy production, due to these conditions, glucose, amino acids are maintained, but fats, ketone bodies, are mobilized for energy production ${ }^{6}$. On the other hand, urea is the degradation product of amino acids, in ruminants, this urea can be recycled and return to the rumen through the saliva or the ruminal wall, once present in the rumen, it is reconverted into ammonia which can serve for the synthesis of amino acids by the ruminal microbiota, and these, in turn, as a source of energy after intestinal absorption ${ }^{4}$.

The breeding of CSA constitutes the main means of productive use of large extensions of natural pastures, in the high areas of the Andes where it is not possible to breed other domestic species or agriculture, the alpaca, efficiently converts natural vegetation of these environments into fiber and meat for human consumption ${ }^{7}$. However, the rearing conditions of the CSA, the seasonal variability of the nutritional resources determine that they have to go through nutritional limitations during the dry season and, in many cases, for prolonged periods of fasting $^{8}$. The alpaca, like the other CSAs, are species 
that have evolved efficiently in environments with serious environmental limitations but are not yet well understood ${ }^{9}$. During fasting, these animals can use free fatty acids (FFA) and ketone bodies (KB) more effectively and do not need to depend entirely on the biochemical pathways of classical ruminants for their energy and glucose requirements ${ }^{10}$.

In one study, plasma glucose, creatinine, and urea concentrations in flames were reported to be higher than sheep and goats, but very low in ketone bodies $(\beta \text {-hydroxybutyrate })^{11}$. The high level of glycemia can be explained in part by a poor response to insulin or by reduced sensitivity of the tissue to insu$\operatorname{lin}^{12}$. Furthermore, CSAs cover their glucose requirements through the gluconeogenesis process from the amino acids of the microbial protein and not from propionate, as occurs in ruminants ${ }^{9}$.

These characteristics imply the need for a dietary scheme based on the protein-fat ratio and not on the protein-carbohydrate ratio as in ruminants ${ }^{9}$. For this reason, the study was proposed with the objective of determining some variations in energy metabolism due to the influence of prolonged fasting in alpacas through serum determinations of glucose, total proteins, urea, and ketone bodies.

\section{Materials and methods}

The study was carried out at the "La Raya" Research and Production Center of the National University of the Altiplano-Puno (UNAP), located in the district of Santa Rosa, Melgar province, Puno department, Peru, at an altitude of $4200 \mathrm{~m}$ and between the geographic coordinates of $10^{\circ} 13^{\prime} 33^{\prime \prime} \mathrm{S}$ and $20^{\circ} 57^{\prime} 12^{\prime \prime} \mathrm{W}$. The center is located in the Puna region, with two well-marked seasons: "rainy season" (from December to March) and "dry season" 65 (from April to March). The average rainfall is 932 $\mathrm{mm} /$ year and the temperature varies between $-7{ }^{\circ} \mathrm{C}$ and $15{ }^{\circ} \mathrm{C}$. The pluvial precipitation and temperature determine that the climate is of the humid cold type. The soil in the area is dominated by the species Stipas, Festucas, Muhlenbergias, Calamagrostis, and Distichias, which serve as food for the extensive rearing of alpacas and llamas.

\section{Figure 1 Herd of two-year-old male alpacas (tuis)}

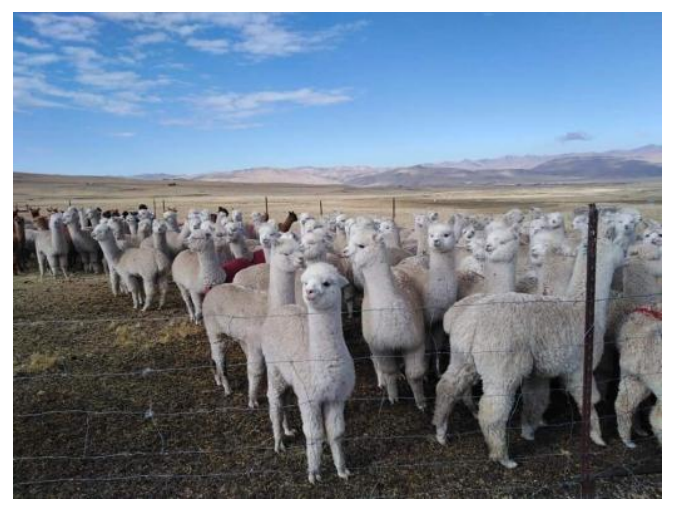

The study was carried out in May 2018. The analysis of the samples was carried out in the Biochemistry Laboratory of the Faculty of Veterinary Medicine and Zootechnics of the UNAP.

\section{Figure 2 Group of fasting animals}

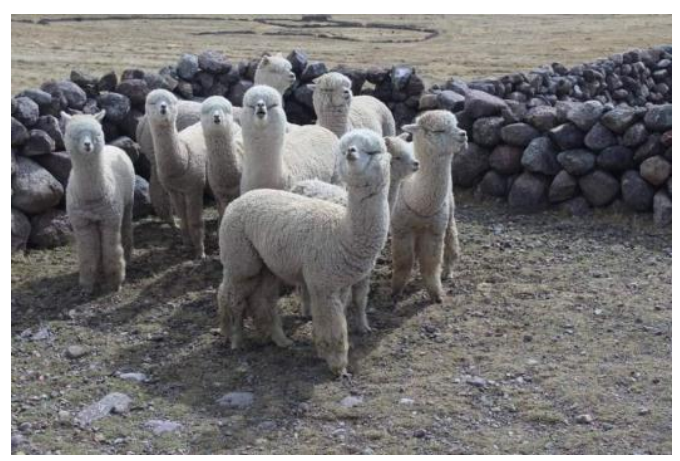

Twenty-two-year-old male alpacas of the Huacaya breed were used in apparent good health, with an average live weight of $47.7 \mathrm{~kg}$. The 20 animals were 
randomly distributed in two treatments of 10 animals each (experimental and control), which were kept in pens built with mesh and wooden posts with an area of $25 \mathrm{~m}^{2}$. The experimental group remained confined during the five days that the experiment lasted, without access to any type of food except water and without prior accustoming period; meanwhile, the control group animals were grazed together with the other animals, consuming the natural pastures of the area. The animals were provided by the Institute for Research and Promotion of South American Camelids (IIPC) of the UNAP.

Figure 3 Animals of the control group

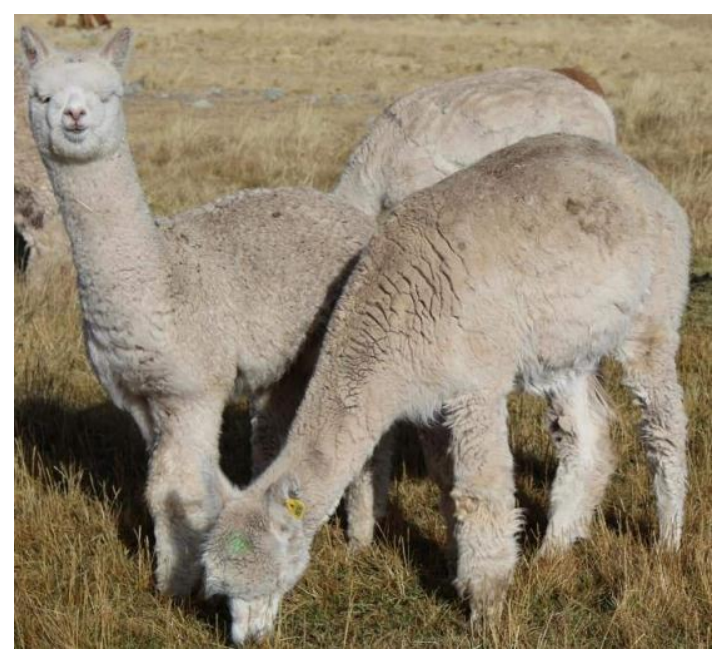

Blood samples were taken at 0, 24, 48, 72, and $96 \mathrm{~h}$ after the start of the experiment (hour 0 from 06:00 h) from all the animals. The samples in the control group were obtained before their departure to the grazing fields. Blood $(5 \mathrm{~mL})$ was obtained from the jugular vein in tubes without anticoagulant, and it was transferred to the laboratory in a refrigerated box. The serum was obtained by centrifugation at $1600 \mathrm{~g}$ for $10 \mathrm{~min}$, and it was decanted into cryogenic vials for its conservation at $-20{ }^{\circ} \mathrm{C}$ until its processing. For the use of animals and obtaining blood samples, we had the authorization of the Ethics Committee of the Faculty of Veterinary Medicine and Zootechnics of the National University of the Altiplano.

The determinations of glucose, total proteins, and urea in the blood serum were carried out by colorimetry-spectrophotometry using reagents from Wiener $L a b \AA$. The determination of ketone bodies was made semi-quantitatively using Siemens ${ }^{\circledR}$ Multistix 10 SG (Bayer) test strips that detect the presence of acetoacetate with a sensitivity of 5 to 10 $\mathrm{mg} / \mathrm{dL}$ and reproducibility of $95 \%$ depending on the insert for use on the package.

The experiment was conducted in a randomized complete block design with sub-sampling (nested), considering as treatment the groups (experimental and control) and blocks at the sampling hours $(0$, $24,48,72$, and 96 h). Duncan's test of significance ${ }^{13}$ was used for the comparison of means of the main effects (groups and sampling times) and for simple effects the LS Means of the SAS v. $9,1^{14}$.

\section{Results}

The concentrations of glucose, protein, urea, and acetoacetate per group according to the time of sampling (fasting) are shown in Table 1. Glucose levels were lower in fasting animals compared to non-fasting animals $(\mathrm{p} \leq 0.05)$; and there are differences between the sampling hours $(p \leq 0.01)$ for the case of fasting animals, but not for the control group animals. In contrast, protein and urea levels are higher in fasting animals than in the control group ( $\mathrm{p} \leq 0.01$ ), as well as between sampling days for fasting animals, but not for their controls $(p \leq 0.01)$. Ketone concentration readings were negative for both treatments (not detected). 
Table 1 Biochemical profile in blood serum of alpacas with and without fasting

\begin{tabular}{|c|c|c|c|c|c|c|c|c|}
\hline \multirow[t]{2}{*}{$\begin{array}{l}\text { Sampling time } \\
\text { (h) }\end{array}$} & \multicolumn{4}{|c|}{ Control (in grasslands) } & \multicolumn{4}{|c|}{ Experimental (fasting) } \\
\hline & $\begin{array}{l}\text { Glucose } \\
\text { (mg/dL) }\end{array}$ & $\begin{array}{c}\text { Protein } \\
\text { (g/dL) }\end{array}$ & $\begin{array}{c}\text { Urea } \\
\text { (mg/dL) }\end{array}$ & $\begin{array}{c}\begin{array}{c}\text { Acetoacetate } \\
(\mathrm{mg} / \mathrm{dL} 9\end{array} \\
\end{array}$ & $\begin{array}{l}\text { Glucose } \\
\text { (mg/dL) }\end{array}$ & $\begin{array}{c}\text { Protein } \\
\text { (g/dL) }\end{array}$ & $\begin{array}{c}\text { Urea } \\
(\mathrm{mg} / \mathrm{dL})\end{array}$ & $\begin{array}{c}\text { Acetoacetate } \\
(\mathrm{mg} / \mathrm{dL})\end{array}$ \\
\hline 0 & $145.7^{\mathrm{a}}$ & $7.05^{\mathrm{a}}$ & $40.5^{\mathrm{a}}$ & n.d. & $145.5^{\mathrm{b}}$ & $6.97^{\mathrm{b}}$ & $40.0^{\mathrm{c}}$ & n.d. \\
\hline 24 & $145.5^{\mathrm{a}}$ & $7.05^{\mathrm{a}}$ & $39.8^{\mathrm{a}}$ & n.d. & $169.1^{\mathrm{a}}$ & $8.45^{\mathrm{a}}$ & $51.2^{\mathrm{b}}$ & n.d. \\
\hline 48 & $144.9^{\mathrm{a}}$ & $7.01^{\mathrm{a}}$ & $41.0^{\mathrm{a}}$ & n.d. & $139.6^{\mathrm{b}}$ & $9.25^{\mathrm{a}}$ & $59.6^{\mathrm{a}}$ & n.d. \\
\hline 72 & $145.5^{\mathrm{a}}$ & $7.00^{\mathrm{a}}$ & $40.8^{\mathrm{a}}$ & n.d. & $126.2^{\mathrm{c}}$ & $9.12^{\mathrm{a}}$ & $61.7^{\mathrm{a}}$ & n.d. \\
\hline 96 & $145.7^{\mathrm{a}}$ & $7.04^{\mathrm{a}}$ & $38.9^{\mathrm{a}}$ & n.d. & $116.4^{\mathrm{d}}$ & $9.09^{\mathrm{a}}$ & $63.5^{\mathrm{a}}$ & n.d. \\
\hline Mean & $145.5^{\mathrm{a}}$ & $7.03^{b}$ & $40.2^{b}$ & & $139.3^{b}$ & $8.58^{\mathrm{a}}$ & $55.2^{\mathrm{a}}$ & \\
\hline
\end{tabular}

\section{Discussion}

The increase in glucose $24 \mathrm{~h}$ after fasting coincides with that reported by Wensvoort et al. ${ }^{10}$ who indicate that under fasting conditions the concentration of blood glucose increases in llamas, camels, and sheep. For their part, Tadich et al. ${ }^{15}$ confirmed that the increase in blood glucose in the first moment is mainly due to stress and not to the effect of fasting, since the initial hypoglycemia acts as a catecholamine-releasing factor, promoting glycolysis and gluconeogenesis, during stress, there is an increase in cortisol, which in turn is hyperglycemic. Similarly, Crossley et al. ${ }^{16}$, when evaluating the adaptive physiological response of the alpaca to the change of environment, found that the blood glucose concentration increases, a fact that is attributed to the stress caused by fasting, confinement, and taking samples.

The average glucose at the beginning of the experiment is within the range established as normal of 112-260 mg/dL by Siguas et al. ${ }^{17}$, and slightly lower than those reported by Kiani et al. ${ }^{11}$ and Al-Rehaimi et al. ${ }^{18}$ who found glucose averages of 127.8 and $138.0 \mathrm{mg} / \mathrm{dL}$ in llamas and camels, respectively, differences that are attributed to the species. However, it is necessary to indicate that glycemia in alpacas, as in other camelids, is higher than other ruminants (cow, sheep, and goats) as reported by Kiani et al. ${ }^{11}$ This physiological hyperglycemia in alpacas is also due to the poor response of insulin and the low concentration of insulin in the serum, proposed by Cebra et al. ${ }^{1}$.

Glucose levels decrease after $24 \mathrm{~h}$, which agrees with Albero et al. ${ }^{2}$, who indicates a rapid decrease in glycemia, but that after $48-72 \mathrm{~h}$ of fasting there is a slow decline until stabilizing. It is pointed out that, in essence, all the glucose available to ruminants, regardless of the diet, comes from gluconeogenesis, the most important precursor of glucose being propionic acid, and added to the constant gluconeogenesis, ruminants also cover their needs for glucose through effective conservation ${ }^{3}$.

The serum protein level at 0 hours $(6.96 \mathrm{~g} / \mathrm{dL})$ coincides with the reports of Oblitas et al. ${ }^{19}$ who report an average concentration of $6.6 \mathrm{~g} / \mathrm{dL}$. In animals deprived of food, total protein levels rise after $24 \mathrm{~h}$. However, this increase is not due to a real increase in proteins in the blood plasma, but rather to dehydration of the individual ${ }^{20}$. Other authors point out 
that in fasting, the kidney becomes the main source of water elimination, observing that in the first 5 to 10 days a strongly negative water balance is observed, even decreasing the density of urine ${ }^{21}$.

The serum urea concentration at the beginning of the experiment $(40.25 \mathrm{mg} / \mathrm{dL})$, is within the range reported by Siguas et al. ${ }^{17}$ (32.2 and $89.8 \mathrm{mg} / \mathrm{dL}$ ). Likewise, it is similar to the value reported by Kiani et al. ${ }^{11}$ who determines uremia of $40.2 \mathrm{mg} / \mathrm{dL}$ for llamas.

Urea levels increase as the days of fasting pass. According to Bustamante ${ }^{22}$, when stressors are perceived, a cascade of events begins, most of them related to the hypothalamic-pituitary-adrenal cortex axis, which finally leads to the release of corticosteroids with certain physiological effects, including hepatic gluconeogenesis catalyzing amino acids and proteins and, therefore, a rise in urea concentration values. For their part, Chowdhury \& Ørskov ${ }^{23}$ indicate that when fasting worsens in ruminants, glucoreceptors in the hypothalamus are stimulated, which stimulates the adrenal medulla to increase adrenaline secretion, which, in turn, activates glycogenolysis, lipolysis, gluconeogenesis Therefore, there will be greater use of intermediaries to produce energy, resulting in increased urinary nitrogen excretion during fasting. Likewise, Wensvoort et al. ${ }^{10}$ indicate that the increase in urea levels during fasting is a sign of an increase in amino acid oxidation to supply glucose precursors through gluconeogenesis.

Ketogenesis is likely to occur in longer periods of fasting, which is why its presence was not detected in the present study. The result agrees with Tadich et al. ${ }^{15}$, who also found no variations in ketone bodies ( $\beta$-hydroxybutyrate) in the fasting of steers during transport to the slaughterhouse, possibly due to the use of the circulating pool of $\beta$-hydroxybutyrate provided by the rumen. For their part, Wensvoort et al. ${ }^{10}$ indicate that camelids could have the capacity to supply enough metabolites for the maintenance of the citric acid cycle and that they could use less or other metabolites in relation to other ruminant species. In this regard, it is pointed out that during the first days of fasting, the animal's energy reserves and gluconeogenesis serve to provide energy to the animal, and ketogenesis is activated when these reserves are depleted. ${ }^{24}$

Chandrasena et al. ${ }^{25}$ found plasma concentrations of 0.089 and $0.148 \mathrm{mg} / \mathrm{dL}$ of $\beta$-hydroxybutyrate and acetoacetate in camels, which are approximately 33 and 4 times lower than for the respective values in sheep, maintained under the same conditions, suggesting that the ketogenesis in camels is very low, a fact that would also be occurring in alpacas since at $96 \mathrm{~h}$ of fasting ketone bodies remain undetectable. Similarly, Kiani et al. ${ }^{11}$ concluded that levels of $\beta$ hydroxybutyrate in llama blood were extremely low for a ruminant animal, such as that found in alpacas in the present study. Thus, it is likely that the metabolism of ketone bodies in the alpaca shows variations with respect to that of other ruminants.

\section{Funding Source}

The study was financed with the authors' own resources.

\section{Conflicts of interest}

The authors declare they have no conflicts of interest with respect to the research, authorship and / or publication of this article.

\section{Acknowledgements}


We are grateful to the Institute for Research and Promotion of South American Camelids (IIPC) of the Faculty of Veterinary Medicine and Zootechnics of UNA-Puno for having provided us with the animals for the study. Likewise, to the technicians Martín Chaiña and Vicente Flores for their support in the construction of the facilities and taking samples of the study.

\section{Ethical aspects}

The study had the approval of the Ethics Committee of the Faculty of Veterinary Medicine and Zootechnics of the National University of the Altiplano and the guidelines established by this Committee were followed.

\section{Cited literature}

1. Cebra CK, Tornquist SJ, Van Saun RJ, Smith BB. Glucose tolerance testing in llamas and alpacas. Am J Vet Res 2001;62(5):682-6. DOI: https://doi.org/10.2460/ajvr.2001.62.682

2. Albero R, Sanz A, Playán J. Metabolismo en el ayuno. Endocrinol Nutr 2004;51(4):139-48. DOI: https://doi.org/10.1016/S1575-0922(04)74599-4

3. Cunningham J. Fisiología Veterinaria. Tercera ed. Madrid, España: ELSEVIER; 2003. DOI: https://doi.org/10.1016/B978-84-9022-317-8/000 $\underline{56-7}$

4. Dukes HH. Dukes'phisiology of domestic animals. 13th ed. John Wiley \& Sons, Inc.; 2015.

5. Lund KE, Milton JTB, Maloney SK, Blache D. Alpacas fed calcium propionate seem to moderate their energy intake. J Anim Physiol Anim Nutr (Berl). 2014;98(6):1088-94. DOI: https://doi.org/10.1111/jpn.12180
6. Mompeán O, Manjón Collado MT, Pérez Sánchez A, Pérez Huertas R. Fisiopatología del ayuno corto y prolongado y del estrés. Rapd Online 2009; 32(1): 45-58.

7. Quispe EC, Rodríguez TC, Iñiguez LR, Mueller JP. Producción de fibra de alpaca, llama, vicuña y guanaco en Sudamérica. Anim Genet Resour Inf 2009;45:1-14. DOI: https://doi.org/10.1017/s101 4233909990277

8. San Martín F, Van Saun RJ. Applied digestive anatomy and feeding behavior. In: Cebra C, Anderson D, Tibary A, Van Saun R, Johnson LR, editors. Llama and alpaca care: Medicine, surgery, reproduction, nutrition, and herd health. Philadelphia: Elsevier; 2014. p. 51-8. DOI: https://doi.org/10.1016/B978-1-4377-2352$\underline{6.00008-0}$

9. San Martín F. Adaptación nutricional y metabólica de los camélidos sudamericanos. En: Aranibar Aranibar MJ, Urviola Sánchez JM, editores. VII Congreso mundial en camélidos sudamericanos. Libro de resúmenes: 28, 29 y 30 de octubre de 2015. Facultad de Medicina Veterinaria y Zootecnia [Internet]. Puno: Universidad Nacional del Altiplano; Corporación Meru EIRL; 2015. [citado 3 de mayo de 2019]. p. 45. Recuperado a partir de: file:///C:/Users/usuario/ Downloads/LibroResumenes\%20(1).pdf

10. Wensvoort J, Kyle D, Ørskov E, Bourke D. Biochemical adaptation of camelids during periods where feed is withheld. Rangifer 2001;21(1):45-8. DOI: https://doi.org/10.7557/ 2.21.1.1527

11.Kiani A, Alstrup L, Nielsen MO. Differential metabolic and endocrine adaptations in llamas, sheep, and goats fed high- and low-protein grassbased diets. Domest Anim Endocrinol 2015;53:9- 
16. DOI: https://doi.org/10.1016/j.domaniend. $\underline{2015.03 .006}$

12.Elmahdi E, Sallmann HP, Fuhrmann H, von Engelhard W, Kaske M. Comparative aspects of glucose tolerance in camels, sheep, horses and ponies. Comp Biochem Physiol A Physiol 1997;118A(1):147-51. DOI: https://doi.org/10. 1016/s0300-9629(96)00449-5

13.Duncan DB. Multiple Range and Multiple F Tests. Biometrics. 1955;11(1):1-42. DOI: https:// doi.org/10.2307/3001478

14.Inc. SI. SAS/STAT ${ }^{\circledR} 9.1$ User's Guide. NC: SAS Institute Inc.; 2004.

15.Tadich N, Gallo C, Echeverría R, van Schaik G. Efecto del ayuno durante dos tiempos de confinamiento y de transporte terrestre sobre algunas variables sanguíneas indicadoras de estrés en novillos. Arch Med Vet 2003;35(2):171-85. DOI: https://doi.org/10. 4067/S0301-732X2003000200005

16.Crossley JC, Marin MP, Ferrando G, Raggi LA. Modificaciones adaptativas de algunas constantes fisiológicas de alpaca (Lama pacos) sometidas a cambios de ambiente. Arch Zootec 1994;43 (163):215-23.

17. Siguas O, Paucar R, Olazabal J, San Martín F, Vélez V. Valores bioquímicos sanguíneos en alpacas en dos épocas del año en condiciones de Huancavelica: Aportes al perfil metabolico de la especie. Arch Latinoam Prod Anim [Internet]. 2007 [citado 5 de octubre de 2019];15 (Suppl. 1): 496-497. Recuperado a partir de: https://www. researchgate.net/publication/284411697 Valores _bioquimicos_en_alpacas_en_dos_epocas_del_a no en condiciones de Huancavelica aportes al _perfil_metabolico_de_la_especie
18.Al-Rehaimi AA, Al-Ali AK, Mutairy AR, Dissanayake AS. A comparative study of enzyme profile of camel (Camelus dromedarius) hump and sheep (Ovis aries) tail tissues. Comp Biochem Physiol 1989;93B(4):857-8. DOI: https://doi.org/10.1016/0305-0491(89)90057-6

19.Oblitas GF, Pedrozo PR, Wittwer MF, Böhmwald H, Ludwing H. Valores sanguíneos en alpacas (Lama pacos) reintroducidas en el sur de Chile. Vet Méx 1998;29(4):411-4.

20.Hervás Abad E, Sánchez Polo MT, García Lopez PJ. Nutrición, ayuno y ejercicio [Internet]. Fundacion para la Formacion e Investigacion Sanitarias de la Region de Murcia. 2012 [citado 3 de mayo de 2019]. Recuperado a partir de: http://www.ffis.es/volviendoalobasico/tema 15 nutricin ayuno y ejercicio.html

21.Saz Peiró P, Ortiz Lucas M. Fisiología y bioquímica en el ayuno. Med Natur 2007;1(1):10-9.

22.Bustamante H. Determinación del efecto de diferentes tiempos de ayuno y transporte terrestre sobre algunas variables sanguíneas indicadoras de estrés en bovinos en el período OtoñoInvierno [tesis licenciatura]. [Valdivia]: Universidad Austral de Chile; 2001.

23. Chowdhury SA, Ørskov ER. Implications of fasting on the energy metabolism and feed evaluation in ruminants. J Anim Feed Sci 1994;3(3):161-9. DOI: https://doi.org/10.22358 /jafs/69830/1994

24.Dukes HH. Dukes' Physiology of domestic animals. $30^{\circ}$. (Reece W, ed.). Oxford: John Wiley \& Sons, Inc.; 2015.

25.Chandrasena LG, Emmanuel B, Hamar DW, Howard BR. A comparative study of ketone body metabolism between the camel (Camelus 
dromedarius) and the sheep (Ovis aries ). Comp Biochem Physiol 1979;64(1):109-12. DOI: https://doi.org/10.1016/0305-0491(79)90192-5

\section{Editor's Note:}

Journal of the Selva Andina Animal Science (JSAAS) remains neutral regarding jurisdictional claims published on maps and institutional affiliations. 